\title{
COGNITIVE ARCHAEOLOGY: IN SEARCH OF THE EARLIEST SYNTACTIC LANGUAGE-USERS IN HIMALAYA
}

\author{
Maheshwar P. Joshi
}

Recent scientific studies unfold that neural structures bearing on intonation of speech have a deep evolutionary history traced to mammal-like reptiles called therapsids found in the Triassic period ( 252.17 mya, million years ago). Therefore, these structures were already present in the primates. It goes to the credit of Homo sapiens who developed it to the extent that humans are defined as symbolling animals, for language is the most articulated symbolism. Cognitive archaeology makes it clear that it took hominins millions of years to develop a syntactic language. Stratigraphically controlled and securely established artefact-bearing sites of the Middle Palaeolithic Arjun complex in the Deokhuri Valley, West Nepal, provide firm dates for the presence of the earliest syntactic language speakers in Himalaya from $100 \mathrm{ka}$ to $70 \mathrm{ka}$ (thousand years ago).

Keywords: cognitive archaeology, neural structure, syntactic language, verbal communication, Arjun complex

\section{Introduction}

Study of prehistory of language falls in the domain of cognitive archaeology and this discipline 'is still in early development' (Renfrew 2008: 67). To the best of my information, no scholar studying South Asian prehistory has addressed this issue despite the fact that South Asia is very rich in material culture vis-à-vis prehistory of language (see for details, Joshi 2014: in press-a; Joshi 2017: in press-b). Since my primary concern in this essay is Himalaya in general and Central Himalaya in particular, I will focus on the earliest syntactic language-users in the context of Central Himalaya.

Recent archaeological investigations in Europe, Africa, and Near East led scholars to formulate two models of language evolution, namely, 'Human Revolution scenario' that credits Europe for this evolution, and 'Out-of-Africa scenario' model that credits it to Africa (see for details and further references, Botha and Knight (eds.) 2009; see also, Possehl 2007; Dennell and Petraglia 2012). Significantly, celebrated cognitive scientist Philip Lieberman's recent studies $(2013 ; 2016)$ clearly show that 'the intonation of speech involves neural structures that have a deep evolutionary history' (Lieberman 2013: Ch. 3, and in passim) and that 'the neural mechanisms implicated in speech production were present in earlier hominins'. It can be 'traced back to therapsids, mammal-like reptiles... of the Triassic, Jurassic, and early Cretaceous eras' (Lieberman 2016: 138), dating back to $\sim 252.17-100.5$ mya. ${ }^{1}$ However, there are progressive stages of language evolution from the ACS (animal communication systems) to protolanguage to fully syntactic language (Calvin and Bickerton 2000; Bickerton 2009). Interestingly, 'syntax evolved gradually in terms of steps or stages' (Botha 2009: 96), i.e., as a 'historical process' (Tomasello 2003), and in syntactic theory 'the grammatical structure of language is the mediator between signal and meaning' (Kinsella 2009: 6, and in passim), thus

Gipan 4. 2019. 1-18. 


\section{2 / Cognitive archaeology...}

suggesting a long process and complex cognitive ability, as Bickerton (2009) has vividly described.

Scholars engaged in probing language evolution have identified certain behavioural traits in archaeological record that imply syntactic language. The widely used evolutionary terminology in prehistoric archaeological record, introduced by Clark (1977 [1961]: 2338, and in passim, table 5) is defined as Mode system of lithic technology. Accordingly, Mode 1 stone tools, also known as Oldowan (dated to 2.6 mya, named after Olduwai Gorge in Tanzania, where they were first discovered), reflect ad hoc lithic technology aimed at obtaining sharp-edged tools. Read with recently discovered Lomekwian tools (dated to 3.3 mya, first discovered at Lomekwi 3 in Kenya, Harmand et al. 2015), Mode 1 are the earliest stone artefacts fashioned by our remote ancestors. These tools suggest that their users had developed slightly higher level of ape grade adaptive behaviour (Wynn and McGrew 1989; Wynn et al. 2011; Davidson and McGrew 2005). Next to Mode 1, appeared Mode 2 lithic technology characterized by the Acheulian biface exhibiting new concept and technology in stone knapping. The name Acheulian was given after the site of St. Acheul on the terraces of the Somme, France, where hand axes were first identified as a distinct prehistoric tool type. Mode 2 technology shows that its users had developed the 'notion of a tool'. It has a deep bearing on the development of cognitive behaviour, for tools knapped in this technology display 'rudimentary ideas of spatial measurement and symmetry' (Wynn and McGrew 1989: 395). Wynn (2002: 398400) contends that this 'artifactual symmetry was not slow and continuous', it was 'the first episode of development' when Homo erectus had appeared in the scene. Wynn's arguments find remarkable support from Stout et al's (2008; see also Semaw et al. 2009) 'positron emission tomography study of functional brain activation during experimental ESA [Early Stone Age] (Oldowan and Acheulean) toolmaking by expert subjects'.

Mode 3 tools characterized by deliberately prepared core technique as exemplified by Levallois is a technological successor to Mode 2 technology. McBrearty and Brooks (2000) have discussed this issue in detail. On the basis of archaeological record and hominin fossils they suggest that appearance of the MSA (Middle Stone Age, corresponding to the Middle Palaeolithic of Europe) coincides with the appearance of fossils attributed to H. Helmei, which may be 'sunk into H. Sapiens' with 'a time depth of ca. 250-300 ka' (Ibid: 529). Defining the behavioural traits of anatomically modern Homo sapiens (AMH), they attribute it to a gradual process of change as evidenced in the African MSA rather than a revolution.

Even if it was not a revolutionary cognitive leap, prepared core technology exemplified by the Levallois is a marked advancement in lithic technology. It is amply clear from Boëda's (1995) graphic study of the Levallois technique that privileges technology over 
style. Scholars are unanimous in that the Levallois technique could be learned only through adequate apprenticeship. Lycett et al (2016: 32) observe:

if any lithic products required active instruction during the Lower-Middle Palaeolithic, then Levallois reduction stands out as the most plausible candidate. This emphasizes the importance of addressing this question, given the implications it might have upon the role of social learning capacities (or lack thereof) in the eventual population replacement of $\mathrm{H}$. neanderthalensis by $\mathrm{H}$. sapiens during the later Pleistocene.

How social learning was carried out? Had humans developed language skills to impart social learning as postulated by Isaac (1976) or else it could be possible without use of language as Wynn (1991) argues. A persuasive study of this kind was first presented by Leroi-Gourhan (1993 [1964]). Leroi-Gourhan (Ibid: 133) notes that we have to 'rely exclusively on the stone industry' to unfold 'technical evolution stretching back from Homo sapiens to the Australanthropians'. Showing critical importance of bipedalism and the anatomical changes that followed, he discusses at great length as to how in sync with these changes our remote ancestors progressively advanced in lithic technology from simple 'choppers' (Mode 1) of the 'pebble culture' to 'microliths' (Mode 5) (Ibid: Chs. 34). He synthesises technical evolution with the capacity of language as follows:

There is probably no reason, in the case of the earliest anthropoids, to separate the level of language from that of toolmaking: Throughout history up to the present time, technical progress has gone hand in hand with progress in the development of technical language symbols. It is possible, in the abstract, to conceive of a purely gestural technical education; in practice, even completely silent instruction will actuate a reflective symbolism in both teacher and pupil. The organic link appears to be strong enough to justify crediting the Australopithecinae [authors of Mode 1 technology] and the Archanthropians [authors of Mode 2 technology] with language at a level corresponding to that of their tools...

Techniques involve both gestures and tools, sequentially organized by means of a "syntax" that imparts both fixity and flexibility to the series of operations involved. This operating syntax is suggested by the memory and comes into being as a product of the brain and the physical environment. If we pursue the parallel with language, we find a similar process taking place...

The early Palaeoanthropians [authors of Mode 3 technology] were the direct inheritors of this situation, but their possibilities became gradually extended. The exteriorization of nonconcrete symbols took place with the Neanderthalians, and technical concepts were thenceforth overtaken by concepts of which we have only manual operating evidence - burial, dyes, curious objects. This evidence, however, is sufficient to establish with certainty that thought was being applied to areas beyond that of purely vital technical motor function...

If language really sprang from the same source as technics, we are entitled to visualize language too in the form of operating sequences limited to the expression of concrete situations, at first concurrently with them and later involving the deliberate preservation and reproduction of verbal sequences going beyond immediate situations (Ibid: 114-16).

It may be noted here that Leroi-Gourhan had developed his theory after receiving adequate training and practice in ethnology, physical anthropology, archaeology, and linguistics, which is a rare feat (White 1993: xiv). It was developed earlier than Noam 


\section{4 / Cognitive archaeology...}

Chomsky's Syntactic Structures (2002 [1957]) that 'was the snowball which began the avalanche of the modern "cognitive revolution." (Lightfoot 2002: v). Interestingly, Leroi-Gourhan's monumental work anticipates nearly all subsequent developments in the field of sensory-based internal systems and material culture vis-à-vis language evolution studies, for subsequent researches in language cognition seem to strengthen his postulates with new data, though his intellectual debt is barely remembered (cf. White 1993).

\section{Language evolution in archaeological record}

According to Marwick (2003), the African evidence suggests use of 'arbitrary bidirectional symbols and expression of displacement communication system' after '1.9' mya when 'the first Homo habilis fossils appear'. This inference is drawn from gradual increase in the distance of raw material transfer from 3 to $13 \mathrm{kms}$ 'during the period 1.91.6' mya, 4 to $15 \mathrm{kms}$ during ' 1.6 to 1.2 ' mya, and ' $15 \mathrm{~km}$ to $100 \mathrm{~km}$ ' after ' 1.2 ' mya. Accordingly, this accounts for human 'ability to pool information collected by individuals through face-to-face negotiation and the use of a protolanguage' (Ibid: 71), which also facilitated human colonization outside Africa. Experimental archaeology also supports that: 'Linguistic communication plays a key role in this system of apprenticeship by facilitating joint action and the cultural construction of identity' (see for details and further references, Stout 2010). Leroi-Gourhan's study demonstrates that 'the process of extraction of a cutting edge from a lump of flint varied in time proportionally with the ratio between the length of cutting edge obtained and the volume of flint required to obtain it', which he explains in 'figure 64' of his work (Leroi-Gourhan 1993 [1964]: 13437). He further shows remarkable similarity in the 'increase in brain volume and technical evolution', which, when translated into a diagram (Ibid: 137-38, figure 65), runs as two almost flat horizontal lines up to the Acheulian (Mode 2 technology), and thereafter 'rise steeply during the Moustero-Levalloisian period' (Mode 3 technology), 'while those representing brain volume flatten out and remain flat until the present day'. Interestingly, Bar-Yosef (2008) draws our attention to the intricacy of Levalloisian technology and states that it involves oral communication to impart this knowledge. He posits that, like Out-of-Africa scenario, the Levalloisian technology was invented in 'a specific region of the Old World and only later spread all over to be shared by many other groups, enriched in due course by a series of additional technical improvements' (Ibid: 376-77; see also, Lieberman 2013: Ch. 5).

Undoubtedly, Mode 3 technology is crucial to explaining the evolution of language from 'protolanguage' stage to 'syntactic' stage. Recent archaeological studies in Central and southern Africa unfold two distinctive phases of Mode 3 technology during the MSA. Thus, stone tools exemplified by segments (somewhat crescent-shaped artefacts, hence also called 'crescents' or 'lunates') with backed retouch appear in small number along with other tools in the earliest Central African MSA ( 300,000 ya), but are rare thereafter. Whether they were used as hand-held scrapers or hafted on bone or wooden handles is uncertain (Deacon and Deacon 1980). However, in the MSA industry called the Howiesons Poort in southern Africa, 'between about 70,000 and 55,000 years ago, segments and other backed tools were the most common stone tools' (Wadley 2010: 
S112). Wadley's (2010) experimental study clearly shows that in the Howiesons Poort industry segments as multipurpose artefacts could be used both as tools and weapons, and their hafting was an intricate process (see, Ibid: s113 for illustrations). Obviously, in the first phase of Mode 3 technology a crescent-shaped artefact appears in small number in the earliest Central African MSA, thereby implying its minimal, limited use. In the second phase, it becomes the most common multipurpose artefact in the Later southern African MSA. These developments implicate social learning by means of demonstration and verbal communication. It will be clear from Wadley's following observations:

Mental rotation, a capacity implying advanced working-memory capacity, was required to place the segments in various positions to create novel weapons and tools. The compound glues used to fix the segments to shafts are made from disparate ingredients, using an irreversible process. The steps required for compound-adhesive manufacture demonstrate multitasking and the use of abstraction and recursion. As is the case in recursive language, the artisan needed to hold in mind what was previously done in order to carry out what was still needed. Cognitive fluidity enabled people to do and think several things at the same time, for example, mix glue from disparate ingredients, mentally rotate segments, talk, and maintain fire temperature. Thus, there is a case for attributing advanced mental abilities to people who lived 70,000 years ago in Africa without necessarily invoking symbolic behaviour (Ibid: S111).

Wadley's observations find remarkable support from cognitive scientist Barnard. Based on his earlier studies spanning over past two decades, Barnard explores how the 'working memory' progressively evolves from 'a four-subsystem architecture' of 'a prototypical mammal' like a zebra to a 'nine-subsystem human architecture' (Barnard 2010). Mammalian minds were augmented by successive interacting 'additions of one new subsystem' ultimately leading to enhanced working-memory capacities in modern humans. He proposes nine-subsystem human architecture in somatic and visceral response mechanism to evaluate 'evidence concerning relationships between cognition and emotion in both normal healthy individuals and those with various psychopathologies'. Accordingly, six-subsystem architecture matches the capability of great apes and by inference of the last common ancestor shared with modern humans. The remaining three subsystems represent the three successive evolutionary steps to attain $H$. Sapiens sapiens architecture (see, Ibid: fig. 3 on page S45). Applying this 'system-level' approach to the archaeological record, he suggests that six-subsystem architecture matches the mental capabilities of great apes and the earliest Homo sapiens (who used Mode 1 technology). He shows 'increasing differentiation limited to the articulatory domain' of Homo erectus, which suggests presence of properties of entities that would 'fit to assign the emergence of a seven-subsystem architecture to Homo erectus' (who used Acheulian technology, i.e., Mode 2). He adds that the Levallois flakes (Mode 3) 'provide good evidence' of eight-subsystem human architecture. Finally, use of intricately prepared compound adhesives in hafting found at Sibudu (also a Mode 3 site, representing Howiesons Poort industry) in southern Africa from 70 kya illustrate the 'nine-subsystem human architecture' as contrasted to the single adhesive use of 'noncompound' materials such as bitumen in Neanderthal hafting. Furthermore, during the nine-subsystem architecture phase we also witness 'appearance of art and personal 


\section{6 / Cognitive archaeology...}

ornamentation and the use of mineral pigments', which are 'all traditionally associated with the emergence of symbolic representation' (Ibid: S51-52; see also Barnard et al 2017). He notes:

The emphasis here on a sequence of well-specified architectures brings into focus the idea that evolution enabled minds with more advanced architectures to do more things at the same time. By the very nature of the sequence, our proposals inherently provide tight couplings between the evolution of cognitive processes, language, meaning, and more refined emotions. The system-level account directs our attention away from evidence pinpointing the emergence of particular capabilities such as the use of iconic, indexical, and symbolic representations and more toward asking questions about the "whole package" of theoretically derived capabilities that come with a mind organized in a particular way (Barnard 2010: S50-S51).

The above summary suggests that oral signalling was central to the social behaviour of our species from Homo erectus to Anatomically Modern Humans and that in terms of evolution stone technology and language run as two parallel rising trajectories over time. It also suggests that cognitive archaeology contributes substantially to the study of origin of language.

\section{Archaeological record of Himalaya}

Archaeological record of Asia clearly shows that the Himalayan region was the cradle of Homo in Asia. This aspect remains almost eclipsed owing to the hegemony of the famous South Indian Acheulian site of Attirampakkam which has been subjected to extensive and intensive studies. It is considered to be a key waypoint in the human expansion from Africa to South Asia and beyond towards East Asia (Dennell 2011). In the following table I have listed some representative prehistoric sites in the Himalaya to show that its rugged terrain was not deterrent to the earliest hominins who made it their cradle.

Table 1: Outline of different techno-facies discovered in Himalaya ${ }^{1}$

\begin{tabular}{|c|c|c|c|c|}
\hline Site/region & Techno-facie & Stratigraphy & Date & Reference \\
\hline $\begin{array}{l}\text { Potwar \& Jammu- } \\
\text { Kashmir }\end{array}$ & $\begin{array}{l}\text { 'Soan' } \\
\text { (Mode } 1 \text { to Mode } 4 \\
\text { type?) }\end{array}$ & $\begin{array}{l}\text { Geological } \\
\text { context } \\
\text { (Now outdated) }\end{array}$ & $\begin{array}{l}\text { Pleistocene } \\
\text { Different glacial } \\
\text { sequences } \\
\text { (Now outdated) }\end{array}$ & $\begin{array}{l}\text { De Terra and } \\
\text { Paterson } \\
1939\end{array}$ \\
\hline $\begin{array}{l}\text { Riwat } \\
\text { Dina \& Jalalpur, } \\
\text { North Pakistan }\end{array}$ & $\begin{array}{l}\text { Pre Acheulian } \\
\text { (Mode 1)* } \\
\text { Acheulian } \\
(\text { Mode } 2)^{*}\end{array}$ & $\begin{array}{l}\text { Geological } \\
\text { context } \\
\text { Geological } \\
\text { context }\end{array}$ & $\begin{array}{l}\sim 2 \text { mya/2.6 mya } \\
0.7 \text { mya \& } 0.4 \\
\text { mya }\end{array}$ & $\begin{array}{l}\text { Dennell et al } \\
1988 / \\
\text { Dennell } \\
2009 \\
\text { Rendell and } \\
\text { Dennell } \\
1985\end{array}$ \\
\hline $\begin{array}{l}\text { Uttarbaini, } \\
\text { Jammu \& Kshmir }\end{array}$ & $\begin{array}{l}\text { Pre Acheulian } \\
\text { (Mode 1)* }\end{array}$ & $\begin{array}{l}\text { Geological } \\
\text { context }\end{array}$ & $2.8 \pm 0.56$ mya & Verma 1991 \\
\hline Nalagarh, & Acheulian & Geological & Pinjor: & Verma 1975 \\
\hline
\end{tabular}

\footnotetext{
${ }^{1}$ Dates taken from International Chronostratigraphic Chart, Cohen et al. 2013, updated; Ward and Kischvink 2015.
} 
Joshi / 7

\begin{tabular}{|c|c|c|c|c|}
\hline Himachal Pradesh & (Mode 2)* & context & Pleistocene & \\
\hline $\begin{array}{l}\text { Masol, } \\
\text { Punjab }\end{array}$ & $\begin{array}{l}\text { Pre Acheulian } \\
(\text { Mode 1)* }\end{array}$ & $\begin{array}{l}\text { Geological } \\
\text { context }\end{array}$ & 2.6 mya & $\begin{array}{l}\text { Malassé et al } \\
2016 / \\
\text { Gaillard } \\
\text { et al } 2016\end{array}$ \\
\hline $\begin{array}{l}\text { Toka, } \\
\text { Himachal Pradesh }\end{array}$ & $\begin{array}{l}\text { Post-Acheulian } \\
\text { 'Mode } 1 \text { and Mode } \\
3{ }^{*}\end{array}$ & $\begin{array}{l}\text { Homogeneity of } \\
\text { artefacts and the } \\
\text { site context }\end{array}$ & $\begin{array}{l}\text { Mid-Late } \\
\text { Pleistocene }\end{array}$ & $\begin{array}{l}\text { Chauhan } \\
2007\end{array}$ \\
\hline $\begin{array}{l}\text { Atbarapur, } \\
\text { Punjab }\end{array}$ & $\begin{array}{l}\text { Acheulian } \\
\text { (Mode 2)* }\end{array}$ & $\begin{array}{l}\text { Homogeneity of } \\
\text { artefacts and the } \\
\text { site context }\end{array}$ & $\begin{array}{l}\text { Upper Siwalik } \\
\text { sediments, } \\
>0.6 \mathrm{Ma}\end{array}$ & $\begin{array}{l}\text { Gaillard et al } \\
2008\end{array}$ \\
\hline $\begin{array}{l}\text { Dzama Thang, } \\
\text { Spiti Valley, } \\
\text { Himachal Pradesh }\end{array}$ & 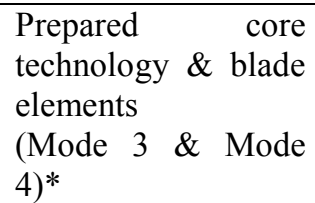 & $\begin{array}{l}\text { Homogeneity of } \\
\text { artefacts and the } \\
\text { site context }\end{array}$ & $\begin{array}{l}\text { Late Pleistocene } \\
50-30 \mathrm{ka}\end{array}$ & $\begin{array}{l}\text { Chauhan et } \\
\text { al 2017/ } \\
\text { Joshi } 2017\end{array}$ \\
\hline $\begin{array}{l}\text { Kalsi, } \\
\text { Uttarakhand }\end{array}$ & $\begin{array}{l}\text { Unifacial \& bifacial } \\
\text { artefacts } \\
\text { (Mode } 1 \text { type) }\end{array}$ & Surface finds & No date & $\begin{array}{l}\text { Verma et al } \\
2012\end{array}$ \\
\hline $\begin{array}{l}\text { Narayan Ganga } \\
\text { Valley, } \\
\text { Uttarakhand }\end{array}$ & $\begin{array}{l}\text { Flakes \& scrapers } \\
\text { Levalloisian } \\
\text { technique } \\
\text { (Mode 3?) }\end{array}$ & Surface finds & No date & IAR 1977-78 \\
\hline $\begin{array}{l}\text { Suwal Valley, } \\
\text { Uttarakhand }\end{array}$ & $\begin{array}{l}\text { Microliths } \\
\text { (Mode } 5 \text { type) }\end{array}$ & Surface finds & No date & $\begin{array}{ll}\text { Joshi } & 1981 ; \\
2008 & \end{array}$ \\
\hline $\begin{array}{l}\text { Gadari. } \\
\text { Satpati Hill. } \\
\text { Brakhuti W. } \\
\text { West Nepal }\end{array}$ & $\begin{array}{l}\text { Acheulian; } \\
\text { Acheulian. } \\
\text { (Mode 2)* } \\
\text { Large flake core } \\
\text { industry } \\
\text { (Mode } 1 \text { type)* }\end{array}$ & $\begin{array}{l}\text { stratigraphical } \\
\text { contex } \\
\text { stratigraphical } \\
\text { contex } \\
\text { stratigraphical } \\
\text { contex }\end{array}$ & $\begin{array}{l}>\text { early Mid- } \\
\text { Pleistocene } \\
\text { Early } \\
\text { Pleistocene to } \\
\text { early Middle } \\
\text { Pleistocene } \\
>\text { early Mid- } \\
\text { Pleistocene }\end{array}$ & $\begin{array}{l}\text { Corvinus } \\
2007\end{array}$ \\
\hline $\begin{array}{l}\text { Arjun complex, } \\
\text { West Nepal }\end{array}$ & 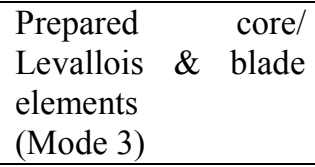 & $\begin{array}{l}\text { stratigraphical } \\
\text { contex }\end{array}$ & $\begin{array}{l}\text { Eemian age } \\
100 \mathrm{ka} \text { to } 70 \mathrm{ka} \\
\text { (Middle } \\
\text { Palaeolithic) }\end{array}$ & $\begin{array}{l}\text { Corvinus } \\
2007\end{array}$ \\
\hline $\begin{array}{l}\text { Brakhuti Industry, } \\
\text { West Nepal }\end{array}$ & 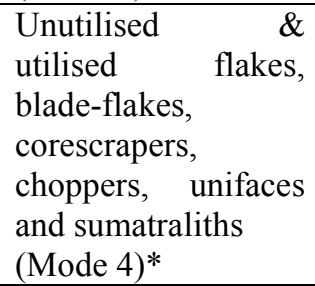 & $\begin{array}{l}\text { stratigraphical } \\
\text { contex }\end{array}$ & $\begin{array}{l}25 \text { to } 40 \mathrm{ka} \\
\text { (Upper } \\
\text { Palaeolithic) }\end{array}$ & $\begin{array}{l}\text { Corvinus } \\
2007\end{array}$ \\
\hline $\begin{array}{l}\text { Ammapur, } \\
\text { Lamahi, \& } \\
\text { Bhatarkund }\end{array}$ & $\begin{array}{l}\text { Microlithic } \\
(\text { Mode 5)* }\end{array}$ & $\begin{array}{l}\text { stratigraphical } \\
\text { contex }\end{array}$ & Late Pleistocene & $\begin{array}{l}\text { Corvinus } \\
2007\end{array}$ \\
\hline
\end{tabular}


8 / Cognitive archaeology...

\begin{tabular}{|c|c|c|c|c|}
\hline West Nepal & & & & \\
\hline $\begin{array}{l}\text { Chabeni, } \\
\text { West Nepal } \\
\text { Patu, } \\
\text { Eastern Nepal. }\end{array}$ & Mesolithic & $\begin{array}{l}\text { stratigraphical } \\
\text { contex }\end{array}$ & Before $7,000 \mathrm{BP}$ & $\begin{array}{l}\text { Corvinus } \\
2007\end{array}$ \\
\hline $\begin{array}{l}\text { Garo Hills } \\
\text { Assam }\end{array}$ & $\begin{array}{l}\text { Assorted tools } \\
\text { (Mode } 1 \text { to Mode } 5 \\
\text { types?) }\end{array}$ & Surface finds & No date & $\begin{array}{l}\text { Sankalia } \\
\text { 1974; } \\
\text { Sharma } \\
\text { 1974; 1979; } \\
\text { Sharma 1996 }\end{array}$ \\
\hline $\begin{array}{l}\text { Kale, Teehum, } \\
\text { Glow, Alubari \& } \\
\text { Chamba, } \\
\text { Arunachal } \\
\text { Pradesh }\end{array}$ & $\begin{array}{l}\text { Assorted tools } \\
\text { (Mode } 1 \text { to Mode } 4 \\
\text { types?) }\end{array}$ & Surface finds & No date & $\begin{array}{l}\text { Sharma } \\
\text { 1979; } \\
\text { Sharma } 1996\end{array}$ \\
\hline $\begin{array}{l}\text { Khangkhul } \\
\text { Khullen, } \quad \& \\
\text { Agartala, } \\
\text { Manipur }\end{array}$ & $\begin{array}{l}\text { Assorted tools } \\
\text { (Mode } 1 \text { to Mode } 5 \\
\text { types?) }\end{array}$ & Surface finds & No date & $\begin{array}{l}\text { Sharma } \\
\text { 1979; } \\
\text { Sharma } 1996\end{array}$ \\
\hline $\begin{array}{l}\text { Teliamura, } \\
\text { Jirania, Sonai } \\
\text { Bazar, Sonaram, } \\
\text { Mohanpur, } \\
\text { Agartala, \& } \\
\text { Jamjuri }\end{array}$ & $\begin{array}{l}\text { Assorted tools } \\
\text { (Mode } 1 \text { to Mode } 5 \\
\text { types?) }\end{array}$ & Surface finds & No date & Sharma 1996 \\
\hline
\end{tabular}

* sensu Clark 1977 [1961].

The above table makes it clear that next to Africa the earliest hominin activities are witnessed in the Himalaya. However, as may be noticed, barring few sites, most of the Palaeolithic find-spots in Himalayan region are surface finds (cf. Chauhan 2007). However, the monumental work of Corvinus (2007) in Nepal compensates for this deficiency. It deals with 'mostly stratigraphically controlled' and 'more or less securely established' artefact-bearing sites in Central and adjoining West Nepal in 'a chronological order' dating back from the Lower Palaeolithic through the Neolithic. Furthermore, it situates these sites in appropriate South Asian, East Asian, and Southeast Asian archaeological context. It unfolds existence of discrete stages of techno-cultural complexes from Mode 1 to Mode 5. Significantly, Corvinus reports Acheulian bifaces from Gadari in the Babai Valley, which is 'barely $15 \mathrm{~km}$ away' from Brakhuti W. in the Tui Valley where she discovered 'large, almost huge flakes and cores and one large uniface' but 'no true bifaces' (Ibid: 87), apparently representing Mode 1 technology. This situation clearly unfolds simultaneous occurrences of two discrete technologies (large flake core industry and Acheulian) in close geographical proximities of each other within the Babai formation, thus challenging both environmental and technological determinism in Himalayan prehistory. 
Thus, Corvinus' work serves as an index to the prehistory of the Himalaya. What is central to present study is the presence of discrete Middle Palaeolithic (Mode 3) technocultural complex in the Deokhuri Valley, with 'Arjun 3' as the principal site (Ibid: 180). Arjun complex has yielded, among others, prepared cores some bearing 'Levallois element'. As noted above, the MSA/the MP marks quantum leap forward in human cognition and matching language acquisition skills as is evident from Wadley's (2010) study of the Howiesons Poort MSA industry and Barnard's (2010) study of the 'ninesubsystem human architecture', cited above. According to Corvinus, the 'artefact horizon' of the Middle Palaeolithic Arjun complex 'has an age of somewhat 100 ka to 70 $\mathrm{ka}$, as on geological and sedimentological ground one would estimate an Eemian age' (Ibid: 183-84). Applying Wadley's and Barnard's studies to Himalayan evidence, it may be suggested that hominins using syntactic language were widespread in Himalaya (Table 1, showing widespread Mode 3 technology exemplified by Levalloisian cores and flakes from Kashmir to Arunachal Pradesh), and that in West Nepal their presence is securely dated to between 100 and $70 \mathrm{ka}$.

Admittedly, language is the most articulated symbolism in human culture, but Mode 3 artefacts mentioned in Table 1 above cannot be cited in the context of symbolic behaviour. For this purpose we invoke rock drawings, which are also widely distributed in the Himalayan region. Table 2 gives relevant information about the distribution of representative regions in Himalaya bearing petroglyphs and pictographs dating back from the Upper Palaeolithic to the Bronze Age.

Table 2: Profile of petroglyphs and pictographs reported from Himalaya

\begin{tabular}{|c|c|c|c|c|}
\hline Region & Idiom & Theme & Date & Reference \\
\hline $\begin{array}{l}\text { Eastern } \\
\text { Himalaya }\end{array}$ & Petroglyphs & $\begin{array}{l}\text { Depressions/zoomorphs/ } \\
\text { anthropomorphs/ } \\
\text { floral/geometric motifs. }\end{array}$ & $\begin{array}{l}\text { Uncertain } \\
\text { Neolithic(?) }\end{array}$ & Bezbaruah 2014 \\
\hline $\begin{array}{l}\text { Central } \\
\text { Himalaya }\end{array}$ & Petroglyphs & $\begin{array}{l}\text { Depressions/zoomorphs/ } \\
\text { anthropomorphs/ } \\
\text { floral/geometric motifs. }\end{array}$ & $\begin{array}{l}\text { 'older than the } \\
\text { Neolithic' }\end{array}$ & Pohle 2003 \\
\hline Nepal & Petroglyphs & $\begin{array}{l}\text { Depressions/zoomorphs/ } \\
\text { floral/geometric motifs }\end{array}$ & $\begin{array}{l}\text { Lower } \\
\text { Palaeolithic (?) } \\
\text { to Megalithic. }\end{array}$ & $\begin{array}{l}\text { Rivett-Carnac } \\
1877 ; \quad \text { Joshi } \\
\text { 1987; 2014: In } \\
\text { press-a }\end{array}$ \\
\hline Uttarakhand & Pictrographs & $\begin{array}{l}\text { Zoomorphs/ } \\
\text { anthropomorphs/ } \\
\text { floral/geometric motifs }\end{array}$ & $\begin{array}{l}\text { Upper } \\
\text { Palaeolithic to } \\
\text { Epipalaeolithic }\end{array}$ & $\begin{array}{l}\text { Joshi } 1974 ; \\
\text { 2014: In press-a }\end{array}$ \\
\hline $\begin{array}{l}\text { Himachal } \\
\text { Pradesh } \\
\text { Spiti Valley }\end{array}$ & $\begin{array}{l}\text { Petroglyphs } \\
\text { and } \\
\text { pictographs }\end{array}$ & $\begin{array}{l}\text { Depressions/zoomorphs/ } \\
\text { anthropomorphs/ } \\
\text { floral/geometric motifs }\end{array}$ & $\begin{array}{l}\text { Mesolithic (?) } \\
\text { to Bronze Age } \\
\text { (excluding } \\
\text { Buddhist) }\end{array}$ & $\begin{array}{l}\text { Bellezza 2015; } \\
\text { Chauhan and } \\
\text { Joshi 2017; Joshi } \\
\text { 2017; Joshi et al } \\
\text { 2017; Dowad } \\
\text { and Norbu } 2017\end{array}$ \\
\hline $\begin{array}{l}\text { Kashmir, } \\
\text { adjoining }\end{array}$ & $\begin{array}{l}\text { Petroglyphs } \\
\text { and }\end{array}$ & $\begin{array}{l}\text { Depressions/zoomorphs/ } \\
\text { anthropomorphs/ }\end{array}$ & $\begin{array}{l}\text { Mesolithic (?) } \\
\text { to Bronze Age }\end{array}$ & $\begin{array}{l}\text { Allchin 1987; } \\
\text { Bruneau 2007; }\end{array}$ \\
\hline
\end{tabular}


10 / Cognitive archaeology...

\begin{tabular}{|l|l|l|l|l|}
\hline North- \\
Pakistan, \\
Western pictographs & floral/geometric motifs & (excluding & Bruneau and \\
Tibet \& & & & & Buddhist) \\
Afghanistan & & & & Olivieri 2010; \\
\hline
\end{tabular}

Despite several scientific attempts at dating prehistoric rock drawings 'a reliable scientific method to establish their absolute antiquities' is yet to come into view (Watchman 1997: 21). Therefore, scholars take into account circumstantial, inferred archaeological, comparative, and stylistic grounds to work their chronology. Accordingly, some of the petroglyphs, notably, large depressions probably used as containers, may belong to the early Palaeolithic, while dates of the remaining ones are uncertain as they are found in different archaeological contexts (Joshi 1987; 1988; 2014: in press-a). As regards the rock paintings, the ones from Uttarakhand are class by themselves and the earliest seem to be contemporaneous, if not earlier, with the earliest rock paintings of Bhimbetka assigned to ' $40,000-15,000$ ' by Wakankar (1984). Thus, there is a strong probability that the earliest rock paintings in Uttarakhand belong to the Upper Palaeolithic and the latest one the Epipalaeolithic (Joshi 2014: in press-a; Joshi et al. 2017). No doubt, it is speculative and subject to sudden death the moment a compelling scientific method is developed in the light of which these drawings declared Neolithic or much later. Nevertheless, the symbolic aspect of these rock drawings cannot be overlooked. It seems that prehistoric community resorted to depictive symbolism, what Leroi-Gourhan's pioneering study terms as 'The Birth of Graphism' (Leroi-Gourhan 1993 [1964]: 187-216), to give expression to its perception of mundane as well as metaphysical world effectively owing to deficiency in spoken language. It was the initial stage of syntactic language.

\section{Situating the earliest language-users of Himalaya in archaeology}

The Himalayan region is a depository of amazingly large number of languages belonging to four major language families, namely, Indo-European, Tibeto-Burman, Austroasiatic, and Dravidian. It also preserves two language isolates, namely, Burushaski, spoken in the central Hunza Valley of northern Pakistan, and Kusunda, spoken in Central and West Nepal by a precariously small group of former foragers commonly known as 'Ban Raja' (Blench 2008: 160-61). Furthermore, origin of Raute or Raji, the language of the huntergatherer group variously called Raute, Raji, Banraja or Banraji (Bandhu 2017; Rastogi 2017), which occupy forests of Far West Nepal and eastern Kumaon (Uttarakhand), also remains disputed (Krishnan cited in Zoller 2016: 3). There is thus a strong probability of survival of some elements of language(s) of the authors of Mode 3, Mode 4, and Mode 5 stone tools and prehistoric rock paintings of Himalaya in extant language isolates, or else in substrate words of unknown origin in all the extant languages. In this connection, we must take into account the fact that in the above-mentioned four major language families Austroasiatic is the oldest and largest language family, the remaining three belong to the named language family category. Austroasiatic has several branches and Munda is one of its 'primary' branches (Blust 2013: Ch. 11; see also Kumar and Reddy 2003; Sidwell 2015; cf. Majumdar 2010). According to Sharma (2003), Munda is the sub-stratum of 
'Tibeto-Himalayan languages'. Therefore, there are three major candidates, namely, Munda, Burushaski, and Kusunda, whose roots may go back to the Middle Palaeolithic. It will be clear from what follows.

Let us begin with the language isolate Burushaski of central Hunza Valley in the Karakoram massif. According to consensus view, it belongs to the Dene-Caucasian language family, which also includes Basque. Basque is 'related to the language spoken by Cro-Magnons, the first modern humans in Europe' (Cavalli-Sforza 2001: 112, 121, 141-42, 149, 158; see also, Piazza and Cavalli-Sforza 2006). In sum, roots of Basque go back to at least the Upper Palaeolithic. What about Burushaski? On the analogy of Basque, it can be suggested that the forebears of Burushaski speakers may also have been related to the authors of different stages of Mode 3 and Mode 4 technologies, namely, 'proto-Levalloisian [Mode 2?], early Levalloisian, distinctly Levalloisian [Mode 3], and late Levalloisian of Europe [Mode 4?]', discovered in neighbouring Potwar and Kashmir region (Paterson 1939: 303, 307-10).

The other language isolate found in Himalaya is Kusunda, spoken in Central and adjoining West Nepal. Not far towards south of Kusunda speakers, Corvinus discovered several sites yielding the Middle and the Upper Palaeolithic tools in the Dang-Deokhuri Valleys with Arjun 3 as the representative Middle Palaeolithic site, mentioned above. Evidently, Kusunda-speaking folks are also found in close proximity of archaeological sites yielding Mode 3, Mode 4, and Mode 5 tools. Therefore, as in case of Burushaski, the forebears of Kusunda speakers may also be associated with the authors of Mode 3, Mode 4, and Mode 5 tools. It is interesting to note that in some recent linguistic studies it has been suggested that Kusunda also belongs to Dene-Caucasian family of languages (van Driem 2008; Bengtson 2009). However, Gerber's (2017) recent detailed combined study of Burushaski, Kusunda, Yenisseian and Athabaskan-Eyak-Tlingit languages suggests that though they are 'typologically similar', particularly in 'complex verbal morphology', it does not 'provide evidence for genealogical relationship' (Ibid: 191-92). Interestingly, recent linguistic and genome studies have complicated the identity of the Kusundaspeaking people because of Kusunda's closeness to 'Indo-Pacific family of languages' (Whitehouse et al. 2004; Rasmussen et al. 2011).

Thus, the issue is still open, and Kusunda's relationship with Dene-Caucassian vis-à-vis Austroasiatic remains ambivalent. What is certain, however, is that the earliest syntactic language-users were roaming in Himalaya at least between $100 \mathrm{ka}$ and $70 \mathrm{ka}$. These dates are considerably older than the linguistic reconstruction of the prehistory of Himalayan languages that hardly conceives beyond the Neolithic agricultural dispersal (see for example, van Driem 2011).

\section{Conclusion}

In the preceding sections of this essay we have seen that archaeological record unfolds that Himalaya witnessed the earliest human activities in Asia, and that these early hominins were equipped with the neural mechanisms that implicated speech production which has a deep evolutionary history. We have also noticed that during the period of 


\section{2 / Cognitive archaeology...}

Mode 3 technology hominins developed complex process of manufacturing glue to fashion a tool with jointed parts, such as a barbed spear. To impart knowledge of this technology required adequate verbal communication. Thus, presence of Mode 3 technology implicates syntactic language. However, Mode 3 tools cannot be cited as evidence for symbolic behaviour in which language plays central role (see for details, Deacon 1997).

Archaeological evidence brings to light that the MSA/the MP characterised by Mode 3 heralds a graduated and punctuated growth towards modern human behaviour (see for a detailed discussion and further references, McBrearty and Brooks 2000). The pronounced traits of modern behaviour as noticed in archaeological record during the MSA/the MP are: 'Symbolic behaviour; Regional artefact styles; Self adornment, e.g., beads and ornaments; Use of pigment; Notched and incised objects (bone, egg shell, ocher, stone); Image and representation; Burials with grave goods, ocher, ritual objects' (Ibid: 518-528, Table 3 on page 492). These traits do imply language (Ibid: 486). Since no prehistoric site in the Himalaya has been subjected to extensive excavations, we have hardly any information to trace these traits. We can infer some of these traits from meagre, but vital information from Arjun complex, a conglomeration of the MP sites in Nepal, which clearly suggests structured patterns of raw material use, fashioning and discarding of tools, and land use as may be inferred from Corvinus' following observation:

The composition of artefacts varies among these localities, and this suggests that different activities were carried out at each site. The main site, Arjun 3, displays the definite features of a camp-cum-factory...

The interesting observation is that all localities in the Arjun area, though close to each other, are found in different environmental and geological settings and contain evidence of a variety of activities (Corvinus 2007: 198).

These activities clearly suggest a well-coordinated socio-economic life and adequate communication system, thus implicating syntactic language.

As regards symbolic behaviour, rock paintings of Uttarakhand provide good evidence for it. Though these paintings date back from the Upper Palaeolithic, they display sociocultural concepts of their times which their authors transferred into visual form for public consumption and future references. Some of these activities have been identified by the present author with ancestor worship, and coalition rituals such as trance journeys and spirit possession (Joshi 2014: in press-a; 2017: in press-b). Following McBrearty and Brooks (2000), it may be suggested that some of these concepts may have deeper roots. Such activities could not be carried out in the absence of syntactic language.

In conclusion, the earliest syntactic language-speaking folks were widespread in Himalaya and Arjun complex of West Nepal supplies firm dates of their presence between $100 \mathrm{ka}$ and $70 \mathrm{ka}$. Arguably, the language(s) of the authors of the pre-Neolithic material culture, especially Central Himalayan rock paintings, should survive either in extant language isolates, or else in substrate words of unknown origin in the extant languages of Central Himalaya (Joshi 2014: in press-a). For this reason, we should not be 
surprised to find terminology used in hunting-gathering lifestyle and equipments thereof, kinship and social relations, and rituals and religious beliefs having the same importance in studying the character of the pre-Neolithic languages as the flora and fauna in the language-farming hypothesis of the Neolithic ones. In this respect the Central Himalayan rock paintings and language phyla are indispensable and need adequate multi-disciplinary research.

\section{References}

Allchin, Bridget. 1987. South Asian rock art. Journal of the Royal Society of Arts, 135 (5366): 138-56.

Bandhu, C. M. 2017. Rāuțe and Rāji: Two endangered tribes of Central Himalayas. In: B.K. Joshi and Masheshwar P. Joshi (eds.), Unfolding Central Himalaya: The Cradle of Culture Proceedings of the International Seminar 2015: 81-98. Dehradun: Doon Library and Research Centre and Almora: Almora Book Depot.

Barnard, Philip J. 2010. From executive mechanisms underlying perception and action to the parallel processing of meaning. Current Anthropology, 51 (Supplement 1): S39-S54.

Barnard, Philip, Iain Davidson and Richard W. Byrne. 2017. Toward a richer theoretical scaffolding for interpreting archaeological evidence concerning cognitive evolution. In: Thomas Wynn and Frederick L. Coolidge (eds.). 2017. Cognitive Models in Palaeolithic Archaeology: 45-67. New York: Oxford University Press.

Bar-Yosef, Ofer. 2008. Can Paleolithic stone artifacts serve as evidence for prehistoric language? In: John D. Bengtson (ed.), In Hot Pursuit of Language in Prehistory: Essays in the Four Fields of Anthropology. In Honor of Harold Crane Fleming: 373-79. Amsterdam/Philadelphia: John Benjamins Publishing Company.

Bellezza 2015: See, John V. Belletza's website reporting discoveries of petroglyphs and pictographs in Tibet, Jammu \& Kashmir, and Himachal Pradesh, http://www.tibetarchaeology.com; http://www.tibetarchaeology.com/july-2015/

Bengtson, John D. 2009. "Dene-Yeniseian" and the Rest of Dene-Caucasian: Part 3: The BurushoYeniseian (Karasuk) Hypothesis. Part 4: Burusho-Dene. Working Papers in Athabaskan Languages. http://jdbengt.net/articles/Athabascan2009Bengtsonx.pdf

Bezbaruah, D. 2014. Megalithic monuments and the context of rock art in NE India. In: B.L. Malla (ed.) Rock Art Studies: Concept, Methodology, Context, Documentation and Preservation. New Delhi: Indira Gandhi National Centre for the Arts and Aryan Book International.

Bickerton, Derek. 2009. Adam's Tongue: How Humans Made Language and Language Made Humans. New York: Hill and Wang.

Blench, Roger. 2008. Re-evaluating the linguistic prehistory of South Asia. In: Toshiki Osada and Akinori Uesugi (eds.), Linguistics, Archaeology and the Human Past: 159-178. Occasional Paper 3. Kyoto: Indus Project Research Institute for Humanity and Nature.

Boëda, Eric. 1995. Levallois: a volumetric construction, methods, a technique. In: Harold L. Dibble and Ofer Bar-Yosef (eds.), The Definition and Interpretation of Levallois Technology: 41-68. Madison: Prehistory Press.

Botha, Rudolf. 2009. Theoretical underpinnings of inferences about language evolution: the syntax used at Blombos Cave. In: Rudolf Botha and Chris Knight (eds.), The Cradle of Language: 93111. Oxford: Oxford University Press.

Botha, Rudolf and Chris Knight (eds.). 2009. The Cradle of Language. Oxford: Oxford University Press. 


\section{4 / Cognitive archaeology...}

Blust, Robert. 2013. The Austronesian Languages. Revised Edition. Canberra: Asia-Pacific Linguistics Research School of Pacific and Asian Studies, Australian National University.

Bruneau, Laurianne. 2007. A preliminary study of rock art of the Western Himalaya. Puratattva, 37: 104-11.

Bruneau, Laurianne and John V. Bellezza. 2013. The rock art of Upper Tibet and Ladakh: Inner Asian cultural adaptation, regional differentiation and the Western Tibetan Plateau Style. Revue d'Etudes Tibetaines, 2013, 28: 5-161. < halshs-00947955>

Calvin, William. H. and Derek Bickerton. 2000. Lingua ex Machina. La conciliación de las teorías de Darwin y Chomsky sobre el cerebro humano. Cambridge, Massachusetts: The MIT Press.

Cavalli-Sforza, Luigi Luca. 2001. Genes, Peoples and Languages. Translated by Mark Seielstad. London: Penguin Books.

Chauhan, Hari and Maheshwar P. Joshi. 2017. Petroglyphs, rock paintings and symbolic behaviour: Recent discoveries in Himachal Pradesh (A preliminary study). In: Hari Chauhan (ed.), Rediscovering Spiti: A Historical and Archaeological Study: 14-39. Shimla: State Museum.

Chauhan, Parth R. 2007. Soanian cores and core-tools from Toka, Northern India: Towards a new typo-technological organization. Journal of Anthropological Archaeology, 26: 412-441.

Chauhan, Hari, Surender Kumar, Narendra Kumar and Vikas Baniyal. 2017. Newly discovered Palaeoliths from the Spiti Valley (Himachal Pradesh): A preliminary study. In: Hari Chauhan (ed.), Rediscovering Spiti: A Historical and Archaeological Study: 1-13. Shimla: State Museum.

Clark, Grahame. 1977 [1961]. World Prehistory: In New Perspective. Third Edition. Cambridge: Cambridge University Press.

Chomsky, Noam. 2002 [1957]. Syntactic Structures. Second Edition: With an Introduction by David W. Lightfoot. Berlin: Mouton de Gruyter.

Cohen, K.M., S.C. Finney, P.L. Gibbard, and J.-X. Fan. 2013; updated. The ICS International Chronostratigraphic Chart. Episodes, 36: 199-204. URL: http://www.stratigraphy.org/ICSchart/ChronostratChart2015-01.pdf

Corvinus, Gudrun. 2007. Prehistoric Cultures in Nepal: From the Early Palaeolithic to the Neolithic and the Quaternary Geology of the Dang-Deokhuri Dun Valleys, Vol. 1 (text) and Vol. 2 (Plates). Wiesbaden: Harrassowitz Verlag.

Davidson, Iain and William C. McGrew. 2005. Stone tools and the uniqueness of human culture. Journal of Royal Anthropological Institute, (N.S.) 11: 793-817.

Deacon, Hilary J., and Janette Deacon. 1980. The hafting, function and distribution of small convex scrapers with an example from Boomplaas Cave. South African Archaeological Bulletin, 35 (131): 31-37.

Deacon, Terrence W. 1997. The Symbolic Species: the Co-evolution of Language and the Brain. New York: W. W. Norton \& Company.

Dennell, R.W. 2009. The Palaeolithic Settlement of Asia. Cambridge: Cambridge University Press.

Dennell, R.W., H. M. Rendell and E. Hailwood. 1988. Late Pliocene artefacts from Northern Pakistan. Current Anthropology, 29 (3): 495-498.

Dennell, Robin. 2011. An Earlier Acheulian Arrival in South Asia. Science, 331 (1532). DOI: $10.1126 /$ science. 1203806

Dennell, Robin and Michael D. Petraglia. 2012. The dispersal of Homo sapiens across southern Asia: how early, how often, how complex? Quaternary Science Reviews, 47: 15-22.

de Terra, H. and T.T. Paterson.1939. Studies on the Ice Age in India and Associated Human Cultures. Washington: Carnegie Institute Publication No. 493. 
Dowad, Michael and Tsering Norbu. 2017. Spiti River Valley rock art: A preliminary study. In: Hari Chauhan (ed.), Rediscovering Spiti: A Historical and Archaeological Study: 40-102. Shimla: State Museum.

Gaillard, Claire, Mukesh Singh, Anne Dambricourt Malassé, Vipnesh Bhardwaj, Baldev Karir, Amandeep Kaur, Surinder Pal, Anne-Marie Moigne, Cécile Chapon Sao, Salah Abdessadok, Julien Gargani and Alina Tudrynd. 2016. The lithic industries on the fossiliferous outcrops of the Late Pliocene Masol Formation, Siwalik Frontal Range, northwestern India (Punjab). C. R. Palevol (2016), http://dx.doi.org/10.1016/j.crpv.2015.09.017

Gaillard, Claire, Mukesh Singh and Kulbhushan Kumar Rishi.2008. Technological analysis of the Acheulian assemblage from Atbarapur in the Siwalik Range (Hoshiarpur District, Punjab). Man and Environment, XXXIII (2): 1-14.

Gerber, Pascal. 2017. The Dene-Kusunda hypothesis: a critical account. Man in India, 97 (1): 111204. file:///C:/Users/user/Desktop/gerber-dene-kusunda-hypothesis.pdf

Harmand, Sonia, Jason E. Lewis, Craig S. Feibel, Christopher J. Lepre, Sandrine Prat, Arnaud Lenoble, Xavier Boës, Rhonda L.Quinn, Michel Brenet, Adrian Arroyo,Nicholas Taylor, Sophie Clément, Guillaume Daver, Jean-Philip Brugal, Louise Leakey, Richard A. Mortlock, James D. Wright, Sammy Lokorodi, Christopher Kirwa, Dennis V. Kent and Hélène Roche. 2015. 3.3-million-year-old stone tools from Lomekwi 3, West Turkana, Kenya. Nature, 521: 310-15 [310-26]. doi:10.1038/nature14464

Indian Archaeology 1977-78 - A Review.

Isaac, Glynn L. 1976. Stages of cultural elaboration in the Pleistocene: possible archaeological indicators of the development of language capabilities. Annals of the New York Academy of Sciences, 280 (1): 275-288.

Joshi, Maheshwar P. 1974. Newly discovered painted rock shelters from Kumaon. In: G. M. Bhattacharya (ed.), Summaries of Papers. All India Oriental Conference, XXVII Session: 21920. Kurukshetra: Kurukshetra University.

Joshi, Maheshwar P. 1981. Prehistoric remains from Kumaon. Paper presented to the Silver Jubilee Year Conference, Department of Ancient Indian History, Culture and Archaeology, Allahabad: Allahabad University.

Joshi, Maheshwar P. 1987. Dots, cup-marks and pits vis-à-vis megaliths: new evidences from Kumaon. Puratattva, 16: 25-28.

Joshi, Maheshwar P. 1988. Early burial practices in Kumaon: some recent discoveries. Bulletin of Museums and Archaeology in U.P., 41-42: 23-30.

Joshi, Maheshwar P. 2008. Prehistoric cultures of Western Himalaya: some enigmatic issues. In: Hari Chauhan (ed.), Cultural Heritage of Himalaya: 1-19. Chamba: Bhuri Singh Museum.

Joshi, Maheshwar P. 2017. The horse and rider in the rock drawings of Spiti. In: Hari Chauhan (ed.), Rediscovering Spiti: A Historical and Archaeological Study: 119-50. Shimla: State Museum.

Joshi, Maheshwar P. 2014: In press-a. Rock paintings of Central Himalaya and symbolic cognition: a new look at prehistoric rock paintings of South Asia. Ancient India: Bulletin of the Archaeological Survey of India, New Series, Number 2 \& 3.

Joshi, Maheshwar P. 2017: In press-b. Cognition: Some aspects of symbolism in rock drawings of Central Himalaya. Paper presented to the National Seminar on Theoretical and Cognitive Aspects of Rock Art, 3rd-5th April, 2017 at IGNCA, New Delhi.

Joshi, Maheshwar P., Hari Chauhan, Vijay Bahuguna, D.N. Dimri and K.C. Nauriyal. 2017. Petroglyphs and rock paintings of Uttarakhand and Himachal Pradesh: A semiotic study. In: 
16 / Cognitive archaeology...

Sadasiba Pradhan and Dibisat B. Garnayak (eds. 2017), Rock Art in India, Vol. II: 447-67. New Delhi: B.R. Publishing Corporation.

Kinsella, Anna R. 2009. Language Evolution and Syntactic Theory. Cambridge: Cambridge University Press.

Kumar, Vikrant and B. Mohan Reddy. 2003. Status of Austro-Asiatic groups in the peopling of India: An exploratory study based on the available prehistoric, linguistic and biological evidences. Journal of Biosciences, 28 (4): 507-522.

Leroi-Gourhan, André. 1993 [1964]. Gesture and Speech [Le Geste et la parole, 1964]. Translated from the French by Anna Bostock Berger and introduced by Randall White. Cambridge, Massachusetts: An October Book, The MIT Press .

Liberman, Philip. 2013. The Unpredictable Species: What Makes Humans Unique. Princeton: Princeton University Press.

Liberman, Philip. 2016. The evolution of language and thought. Journal of Anthropological Sciences, 94: 127-146. DOI: 10.4436/jass.94029

Lightfoot, David W. 2002. Introduction. In: Noam Chomsky, 2002 (1957), Syntactic Structures: vxviii. Second Edition, With an Introduction by David W. Lightfoot. Berlin: Mouton de Gruyter.

Lycett, Stephen J., Noreen von cramon-taubadel and Metin I. Eren. 2016. Levallois: potential implications for learning and cultural transmission capacities. Lithic Technology, 41 (1): 19-38. DOI: $10.1179 / 2051618515$ Y.0000000012

Majumder, Partha P. 2010. The human genetic history of South Asia. Current Biology, 20: 184187. DOI 10.1016/j.cub.2009.11.053

Malassé, Anne Dambricourt, Mukesh Singh, Baldev Karir, Claire Gaillard, Vipnesh Bhardwaj, Anne-Marie Moigne, Salah Abdessadok, Cécile Chapon Sao, Julien Gargani, Alina Tudryn, Thomas Calligaro, Amandeep Kaur, Surinder Pal, Manjil Hazarika. 2016. Anthropic activities in the fossiliferous Quranwala Zone, 2.6 Ma, Siwaliks of Northwest India, historical context of the discovery and scientific investigations. C. R. Palevol (2016). http://dx.doi.org/10.1016/j.crpv.2015.06.004

McBrearty, Sally and Alison S. Brooks. 2000. The revolution that wasn't: a new interpretation of the origin of modern human behavior. Journal of Human Evolution, 39: 453-563.

Marwick, B. 2003. Pleistocene exchange networks as evidence for the evolution of language. Cambridge Archaeological Journal, 13 (1): 67-81.

Mock, John. 2013. New discoveries of rock art in Afghanistan's Wakhan Corridor and Pamir: A preliminary study. The Silk Road, 11: 36-54.

Olivieri, Luca Maria. 2010. Materials for a Tentative Reconstruction of the Religious and Cultural Stratigraphy of Ancient Swat. Ph. D. Thesis. Universität Berlin.

Paterson, T.T. 1939. Prehistory of the Potwar and Indus regions. In: De Terra, H. and T.T. Paterson. Studies on the Ice Age in India and Associated Human Cultures: 310-12. Washington: Carnegie Institute Publication No. 493.

Piazza, Alberto and Luigi Cavalli-Sforza.2006. Diffusion of genes and languages in human evolution. In: Angelo Cangelosy, Andrew D.M. Smith and Kenny Smith (eds.), The Evolution of Language: Proceedings of the 6th International Conference (EVOLANG6): 255-66. Singapore: World Scientific Publishing Co.

Pohle, Perdita. 2003. Petroglyphs and abandoned sites in Mustang. A unique source for research in cultural history and historical geography. Ancient Nepal, 153: 1-14.

Possehl, Gregory L. 2007. Thoughts on the evolution and history of human populations in South Asia. In: Petraglia, Michael D. and Bridget Allchin (eds.), The Evolution and History of 
Human Populations in South Asia: Inter-disciplinary Studies in Archaeology, Biological Anthropology, Linguistics and Genetics: 447-59. Dordrecht: Springer.

Rasmussen, Morten et al (57 co-authors). 2011. An aboriginal Australian genome reveals separate human dispersals into Asia. Science, 334: 94-98. www.sciencemag.org

Rastogi, Kavita. 2017. Raji: challenges of preservation and revitalization. In: B.K. Joshi and Masheshwar P. Joshi (eds.), Unfolding Central Himalaya: The Cradle of Culture Proceedings of the International Seminar - 2015: 99-113. Dehradun: Doon Library and Research Centre and Almora: Almora Book Depot

Rendell, Hellen M and R.D. Dennell. 1985. Dated Lower Palaeolithic artifacts from northern Pakistan. Current Anthropology, 26: 393.

Renfrew, Colin. 2008. Prehistory: The Making of the Human Mind. E-book. New York: The Modern Library.

Rivett-Carnac, J.H. 1877. Rough notes on some ancient sculpturing on rocks in Kumaon similar to those found in monoliths and rocks in Europe. Journal of Asiatic Society of Bengal, XLVI (1): $1-15$.

Sankalia, H.D. 1974. The Prehistory and Protohistory of India and Pakistan. Poona: Deccan College Postgraduate and Research Institute.

Semaw, Sileshi, Michael Rogers and Dietrich Stout. 2009. The Oldowan-Acheulian transition: is there a "developed Oldowan" artifact tradition?. In: Marta Camps and Parth Chauhan (eds.), Sourcebook of Paleolithic Transitions Methods, Theories, and Interpretations: 173-93. New York: Springer.

Sharma, A.K. 1996. Early Man in Eastern Himalayas (North-East India and Nepal). New Delhi: Agam Books International.

Sharma, T.C. 1974. Recent archaeological discoveries in North-Eastern India. Puratattva, 7: 1719. 1974;

Sharma, T.C. 1979. Prehistoric archaeology in North Eastern India - a review of progress. In: T. C. Sharma and D.N. Majumdar (eds.), Eastern Himalayas (A Study on Anthropology and Tradition): 102-35. New Delhi: Cosmo Publications.

Sharma, D.D. 2003. Munda: Sub-stratum of Tibeto-Himalayan Languages. New Delhi: Mittal Publications.

Sidwell, Paul. 2015. The Austroasiatic language phylum: A typology of phonological restructuring. In: Claire Bowern and Bethwyn Evans (eds.), The Routledge Handbook of Historical Linguistics: 675-703. Oxon: Routledge.

Stout, Dietrich. 2010. Possible relations between language and technology in human evolution. In: April Nowell and Iain Davidson (eds.), Stone Tools and the Evolution of Human Cognition: 159-84. Boulder: University Press of Colorado.

Stout, Dietrich, Nicholas, Kathy Schick and Thierry Chaminade. 2008. Neural correlates of Early Stone Age toolmaking: technology, language and cognition in human evolution. In: Colin Renfrew, Chris Frith and Lambros Malafouris (eds.), The Sapient Mind: Archaeology Meets Neuroscience, 363 (1499): 1939-49. London: Philosophical Transactions of the Royal Society B.

Tomasello, Michael. 2003. On the different origins of symbols and grammar. In: Morten H. Christiansen and Simon Kirby (eds.), Language Evolution: 94-110. Oxford: Oxford University Press.

van Driem, George. 2008. Reflections on the ethnolinguistic prehistory of the Greater Himalayan Region. In: Brigitte Huber, Marianne Volkart and Paul Widmer (eds.), Chomolangma, 
18 / Cognitive archaeology...

Demawend und Kasbek: Festschrift für Roland Bielmeier zu seinem 65: 39-59. Geburtstag (2 vols.). Halle: International Institute for Tibetan and Buddhist Studies.

van Driem, George. 2011. Lost in the sands of time somewhere north of the Bay of Bengal. In: Mark Turin and Bettina Zeisler (eds.), Himalayan Languages and Linguistics: Studies in Phonology, Semantics, Morphology and Syntax: 13-38. Leiden: Brill.

Verma, B.C. 1975. Occurrence of Lower Palaeolithic artefacts in the Pinjor member (Lower Pleistocene) of Himachal Pradesh. Journal of Geological Society of India, 16 (4): 518-521.

Verma, B.C. 1991. Siwalik Stone Age culture. Current Science, 61 (8): 496.

Verma, Niraj Kumar, Manoj Kumar Saxena, Maheshwar P. Joshi, Syed Jamal Hasan and D.N. Dimri. 2012. Newly discovered palaeoliths from Uttarakhand Himalaya, India. Manimahesh: A Journal of Himalayan Studies, 2: 39-44.

Vernier, Martin. 2016. Zamthang, epicentre of Zanskar's rock art heritage. Revue d'Etudes Tibétaines, no. 35, April 2016: 53-105.

Wadley, Lyn. 2010. Compound-adhesive manufacture as a behavioral proxy for complex cognition in the Middle Stone Age. Current Anthropology, 51 (Supplement 1): S111- S119.

Wakankar, V.S.1984. Bhimbetka and dating of Indian rock-paintings. In: Chakravarty, K.K. (ed.), Rock-art of India: Paintings and Engravings: 44-56. New Delhi: Arnold-Heinemann.

Ward, Peter and Joe Kischvink. 2015. A New History of Life: The Radical New Discoveries about the Origins and Evolution of Life on Earth. London: Bloomsbury Press.

Watchman, Alan. 1997. Paleolithic marks: Archaeometric perspectives. In: Margaret W. Conkey, Olga Soffer, Deborah Stratmann and Nina G. Jablonski (eds.), Beyond Art: Pleistocene Image and Symbol: 21-36. Wattis Symposium Series in Anthropology, Memoirs of the California Academy of Sciences, Number 23. California, San Francisco.

White, Randall. 1993. Introduction [to the first English translation of Le Geste et la parole 1964]. In: André Leroi-Gourhan. 1993 (1964). Gesture and Speech. Translated from the French by Anna Bostock Berger and introduced by Randall White. Cambridge, Massachusetts: An October Book, The MIT Press

Whitehouse, Paul, Timothy Usher, Merritt Ruhlen and William S.-Y. Wang. 2004. Kusunda: An Indo-Pacific language in Nepal. PNAS, $101 \quad$ (No. 15): 5692-95. www.pnas.org/cgi/doi/10.1073/pnas.0400233101

Wynn, Thomas. 1991. Tools, Grammar and the archaeology of Cognition. Cambridge Archaeological Journal, 1 (2): 191-206.

Wynn, Thomas. 2002. Archaeology and cognitive evolution. Behavioral and Brain Sciences, 25: 389-438.

Wynn, T. and W.C. McGrew. 1989. An ape's view of the Oldowan. Man (New Series), 24, (3): 383-98.

Wynn, Thomas, R. Adriana Hernandez-Aguilar, Linda F. Marchant, and William C. McGrew. 2011. “An Ape's View of the Oldowan” revisited. Evolutionary Anthropology, 20: 181-197.

Zoller, Claus Peter. 2016. Proto Indo-European - Indo-Aryan - Himalayan Aryan Languages: New Perspectives on Some Old Questions. Dehradun: Doon Library and Research Centre \& $\mathrm{M} / \mathrm{s}$ Bishen Singh Mahendra Pal Singh. 